\title{
Pengaruh Laba Akuntansi, Arus Kas Operasi dan Dividend Yield terhadap Return Saham (Studi pada Perusahaan Manufaktur di Bursa Efek Indonesia)
}

\author{
*Laelatul Nur Kholilik, Siti Rosyafah, Tri Lestari \\ Program Studi Akuntansi Fakultas Ekonomi dan Bisnis \\ Universitas Bhayangkara, Indonesia
}

DOI: $10.46821 /$ equity.v1i2.181

\begin{abstract}
ABSTRAK
Penelitian ini bertujuan untuk menganalisis pengaruh tiga komponen laba akuntansi, arus kas dari operasi, dan dividend yield yang terdaftar di Bursa Efek Indonesia (BEI) selama 2015 hingga 2017. Penelitian ini menggunakan 96 sampel perusahaan manufaktur yang terdaftar di Bursa Efek Indonesia (BEI) selama 2015 hingga 2017. Variabel yang digunakan dalam penelitian ini adalah variabel laba bersih, arus kas operasi, dan dividen yield sebagai variabel independen, dan return saham sebagai variabel dependen. Berdasarkan hasil penelitian yang di uji melalui uji t atau secara parsial oleh uji SPSS disimpulkan bahwa laba akuntansi dan arus kas operasi berpengaruh terhadap return saham, sedangkan dividend yiled tidak berpengaruh terhadap return saham. Untuk hasil uji $F$ disimpulkan bahwa laba akuntansi, arus kas operasi, dividend yiled secara simultan berpengaruh terhadap return saham. Hasil uji variabel yang paling dominan yaitu laba akuntansi karena nilai signifikansinya mendekati nol dan menunjukkan nilai beta paling besar.
\end{abstract}

Kata Kunci: Return Saham, Laba akuntansi, Arus kas Operasi dan Dividend Yield.

\begin{abstract}
This study aims to analyze the influence of three components of net profit, cash flow from operating, and dividend yield to the stock return on manufactur industries listed in Indonesian Stock Exchange (IDX) during 2015 to 2017. This study uses 96 samples of manufacturing firms that listed in Indonesian Stock Exchange (IDX) during 2015 to 2017. Variables used in this study are variable accounting profit, cash flow from operating, and dividend yield as an independent variable, Stock Return as an dependent variable. The results of the research tested through the $t$ test or partially by the SPSS test it was concluded that accounting profit and operating cash flow has an effect on stock returns, while dividends are not affected by stock returns. For the results of the F test it can be concluded that accounting earnings, operating cash flows, dividends are simultaneously paid affect stock returns. The most dominant variable test results are accounting profit because the significance value is close to zero and shows value biggest beta.
\end{abstract}

Keywords: Stock Return, Accounting Profit, Cash Flow from operating and Dividend Yield.

*Corresponding Author:

Email: laylalilik@gmail.com 


\section{PENDAHULUAN}

Salah satu sektor yang terdaftar di pasar modal adalah sektor manufaktur. Sektor manufaktur ini cukup diminati oleh investor karena perkembangan saham sektor ini dari tahun ke tahun cenderung meningkat. Seorang investor menanmkan modalnya tentu mengharapkan return (pengembalian). Return menurut Tandelilin (2001:47) merupakan salah satu faktor yang memotivasi investor berinvestasi dan juga merupakan imbalan atas keberanian investor menanggung resiko atas investasi yang dilakukannya.

Fokus utama dari pelaporan keuangan adalah laba, dan informasi mengenai laba adalah indikator yang baik untuk menentukan kas dimasa yang akan datang, hal ini saling berkaitan yaitu antara arus kas dan laba karena jika perusahaan berhasil memiliki arus kas positif yang besar dari aktivitas operasi perusahaan, maka akan memberikan nilai laba yang baik juga terhadap perusahaan. Disisi lain ukuran perusahaan dapat juga mempengaruhi investor untuk melakukan investasi, rasio pendapatan dividen atau dividend yield, didalam investasi saham, untuk menilai seberapa besar dividend yang diperoleh berdasarkan harga saham yang pada saat dibeli adalah dengan cara mengetahui rasio dividend yield. Semakin besar nilai dividend yield maka semakin besar pula nilai return saham yang diporeoleh.

\section{TINJAUAN PUSTAKA}

\section{Pengaruh Laba Akuntansi Terhadap Return Saham}

Menurut Ghozali dan Chariri (2016:347) dalam bukunya teori akuntansi mendefinisikan "laba akuntansi sebagai perbedaan antara pendapatan yang direalisasi dari transaksi yang terjadi selama satu periode dengan biaya yang berkaitan dengan pendapatan tersebut".

Menurut Husnan dan Pudjastuti (2009:134) perusahaan yang memiliki kemampuan untuk meningkatkan laba, cenderung harga sahamnya juga meningkat. Maksudnya jika sebuah perusahaan memperoleh laba yang lebih besar dan meningkat, maka secara teoritis perusahaan akan mampu membagikan dividen yang lebih besar dan akan berpengaruh secara positif terhadap return saham.

\section{Pengaruh Arus Kas Operasi Terhadap Return Saham}

Arus kas operasi adalah aktivitas penghasil utama pendapatan dalam perusahaan dan merupakan indikator penentu yang menunjukkan kinerja perusahaan serta kemampuan perusahaan dalam menghasilkan laba. Sehingga dengan demikian dari perubahan arus kas dari aktivitas operasi akan memberikan sinyal positif kepada investor dan investor akan membeli saham perusahaan dan pada akhirnya akan meningkatkan return saham.

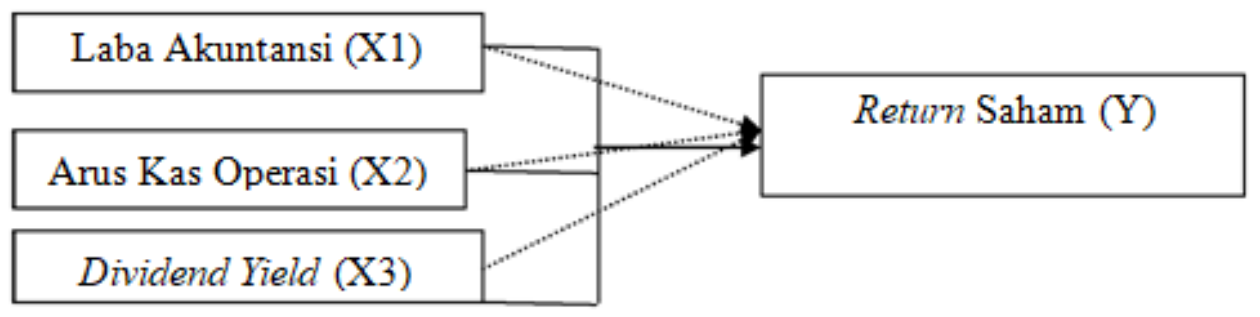

Gambar 1

Kerangka Pemikiran 


\section{Pengaruh Dividend Yield Terhadap Return Saham}

Menurut Hirt (dalam Farah margareta dan Irma Damayanti, 2006:151) dividend yield merupakan hasil presentase dari keuntungan perlembar saham dibagi dengan harga pasar perlembar saham yang diterima perusahaan.

Tingginya suatu dividend yield menunjukkan bahwa suatu saham dalam keadaan undervalued, yaitu jika harga saham lebih kecil dari nilainya, maka saham tersebut harus dibeli dan ditahan sementara dengan tujuan memperoleh capital gain. dividend yield juga menjelaskan return atas indeks tertimbang pada masing-masing perusahaan.

\section{Hipotesis Penelitian}

H1 : Laba Akuntansi, Arus Kas Operasi dan Dividend Yield berpengaruh secara simultan terhadap Return saham perusahaan manufaktur yang terdaftar di Bursa Efek Indonesia.

H2 : Laba akuntansi, Arus Kas Operasi dan Dividend Yield berpengaruh secara parsial terhadap Return saham perusahaan manufaktur yang terdaftar di Bursa Efek Indonesia.

H3 : Terdapat pengaruh dominan antara variabel laba Akuntansi, Arus Kas Operasi dan Dividend Yield terhadap Return saham perusahaan manufaktur yang terdaftar di Bursa Efek Indonesia.

\section{METODE PENELITIAN}

\section{Populasi}

Populasi dalam penelitian ini adalah perusahaan manufaktur sebanyak 96 perusahaan dan ada 20 perusahaan yang terpilih di Bursa Efek Indonesia pada periode tahun 2015 sampai dengan tahun 2017.

\section{Sampel}

Kriteria pengambilan sampel yang digunakan dalam penelitian ini adalah :

a. Perusahaan manufaktur yang sudah go public di BEI.

b. Perusahaan yang telah menerbitkan dan mempublikasikan laporan keuangan auditannya per 31 Desember 2015,2016,dan 2017.

c. Perusahaan yang sahamnya tetap aktif beroprasi mulai tahun 2015-2017.

d. Perusahaan yang telah mempublikasikan annual report/company report tahun 2015-2017.

e. Perusahaan yang secara konsisten membagikan dividen selama periode penelitian yaitu tahun 2015-2017.

f. Memiliki data lengkap yang digunakan sebagai variabel dalam penelitian ini dan secara konsisten dilaporkan di Bursa Efek Indonesia.

\section{Pengumpulan Data}

Teknik pengumpulan data dalam penelitian ini yaitu kuesioner, observasi, dan dokumentasi.

\section{HASIL DAN PEMBAHASAN \\ Deskriptif Sampel Penelitian}

Berdasarkan tabel 1, variabel laba akuntansi menunjukkan bahwa nilai minimum sebesar -0,85, dan nilai maksimum sebesar 13,31. Rata-rata 0,271. Standart deviasi dari laba akuntansi adalah 1,785. Variabel arus kas operasi memiliki nilai minimum sebesar sebesar $-8,01$, dan nilai maksimum 19,25. Untuk besar rata-rata 
arus kas operasi dari jumlah data yang diteliti adalah 0,46. Standart deviasi dari arus kas operasi 3,24. Variabel dividend yield memiliki nilai minimun sebesar 0,77 yaitu pada, dan nilai maksimum dividend yield senilai 195,00. Besar rata-rata dividend yield 3,18 dan Standart deviasi sebesar 27,69. Variabel dependen return saham dengan nilai minimum sebesar $-62,00$, dan nilai maksimum variabel return saham senilai 139,00. Besar rata-rata return saham 2,97 dan Standart deviasi sebesar 39,78 .

\section{Uji Asumsi Klasik}

\section{Uji Normalitas}

Dari gambar 2, terlihat bahwa pola titik-titik menyebar disekitar garis diagonal dan mengikuti arah garis diagonalnya yang berarti data dalam penelitian ini terdistribusi normal.

Berdasarkan tabel 2 dapat diketahui bahwa nilai Kolmogorov-Smirnov sebesar 1,140 dan nilai Asymp. Sig. (2-tailed) sebesar 0,130 yang menunjukkan bahwa lebih besar dari 0,05 , maka dapat dinyatakan bahwa residual terdistribusi normal.

\section{Uji Multikolinieritas}

Berdasarkan tabel 3, diperoleh hasil bahwa nilai Tolerance ketiga variabel ( Laba Akuntansi, Arus Kas Operasi, dan Dividend Yield ) lebih dari 0,10 dan nilai Variance Inflation Factor kurang dari 10. Maka dapat disimpulkan bahwa tidak terjadi masalah multikolinearitas pada model regresi.

\section{Tabel 1}

\section{Statistik Deskriptif}

\begin{tabular}{llllll}
\hline & $\mathrm{N}$ & Minimum & Maximum & Mean & Std. Deviation \\
\hline Laba Akuntasi (X1) & 60 &,- 8500 & 13,3100 &, 271833 & 1,7858535 \\
Arus Kas Operasi (X2) & 60 & $-8,0100$ & 19,2500 &, 469829 & 3,2413296 \\
$\begin{array}{l}\text { Dividend Yield } \\
\text { (X3) }\end{array}$ & 60 &,- 7700 & 195,0000 & 3,187833 & 27,6906136 \\
$\begin{array}{l}\text { Return Saham (Y) } \\
\text { Valid N (listwise) }\end{array}$ & 60 & $-62,0000$ & 139,0000 & 2,971333 & 39,7839379 \\
& 60 & & & & \\
\hline
\end{tabular}

Sumber: Data Diolah, 2018

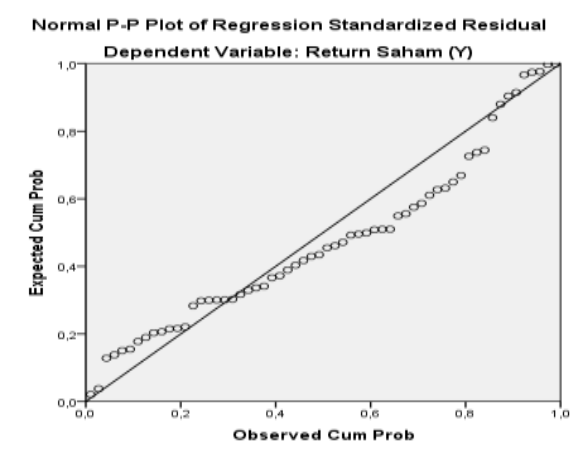

Sumber: Data Diolah, 2018

Gambar 2

Grafik Normal P-P Plot of Regresion Standardized Residual 
Tabel 2

Hasil Uji Kolmogorov-Smirnov One-Sample Kolmogorov-Smirnov Test

\begin{tabular}{|c|c|c|}
\hline & & Unstandardize d Residual \\
\hline $\mathrm{N}$ & & 60 \\
\hline \multirow[t]{2}{*}{ Normal Parameters ${ }^{\mathrm{a}, \mathrm{b}}$} & Mean & ,0000000 \\
\hline & Std. Deviation & 38,79816001 \\
\hline \multirow[t]{3}{*}{ Most Extreme Differences } & Absolute &, 140 \\
\hline & Positive &, 14 \\
\hline & Negative &,- 104 \\
\hline Test Statistic & & 1,140 \\
\hline Asymp. Sig. (2-tailed) & &, 130 \\
\hline
\end{tabular}

Sumber: Data Diolah

Tabel 3

Uji Multikolinearitas

Coefficients $^{\mathrm{a}}$

\begin{tabular}{lllllll}
\hline Model & \multicolumn{3}{c}{ Correlations } & \multicolumn{3}{c}{ Collinearity } \\
& \multicolumn{1}{c}{ Statistics } \\
\cline { 2 - 6 } & Zero- order & Partial & Part & Tolerance & VIF \\
\hline $1 \quad$ (Constant) & & & & & \\
- &,- 042 &,- 036 &,- 035 &, 999 & 1,001 \\
$\quad$ Laba Akuntasi (X1) &, 207 &, 205 &, 205 &, 998 & 1,002 \\
Arus Kas Operasi (X2) &,- 073 &,- 070 &,- 068 &, 999 & 1,001 \\
$\quad$ Dividend Yield (X3) & & & & &
\end{tabular}

Sumber: Data Diolah

Tabel 4

Uji Autokorelasi

Model Summary ${ }^{b}$

\begin{tabular}{cccccc}
\hline Model & R & R Square & Adjusted R Square & $\begin{array}{c}\text { Std. Error of the } \\
\text { Estimate }\end{array}$ & Durbin- Watson \\
\hline 1 & ,519a &, 270 &, 231 & 3072,0596984 & 2,063
\end{tabular}

Sumber: Data Diolah

\section{Uji Autokorelasi}

Berdasarkan tabel 4 dapat diketahui hasil uji autokorelasi yang menunjukkan nilai durbin watson hitung sebesar 2,063. Penelitian ini menggunakan data sejumlah 60 dan variabel independen sebanyak 3 sehingga berdasarkan tabel Durbin Watson diketahui nilai $\mathrm{dl}=1,4943$ dan $\mathrm{du}=1,6932$ (pada tabel $\mathrm{DW})$, serta nilai $(4-\mathrm{du})=$ 2,3068. Nilai 2,063 tersebut lebih besar dari nilai du dan kurang dari 4-du sehingga dapat disimpulkan bahwa dalam dalam model regresi tidak terdapat masalah autokorelasi.

\section{Uji Heteroskedastitas}

Berdasarkan gambar 3, dapat diketahui bahwa titik-titik tidak membentuk pola yang jelas. Titik-tik menyebar diatas dan dibawah angka 0 pada sumbu Y. Jadi dapat disimpulkan bahwa tidak terjadi masalah heteroskedastisitas dalam model regresi. 


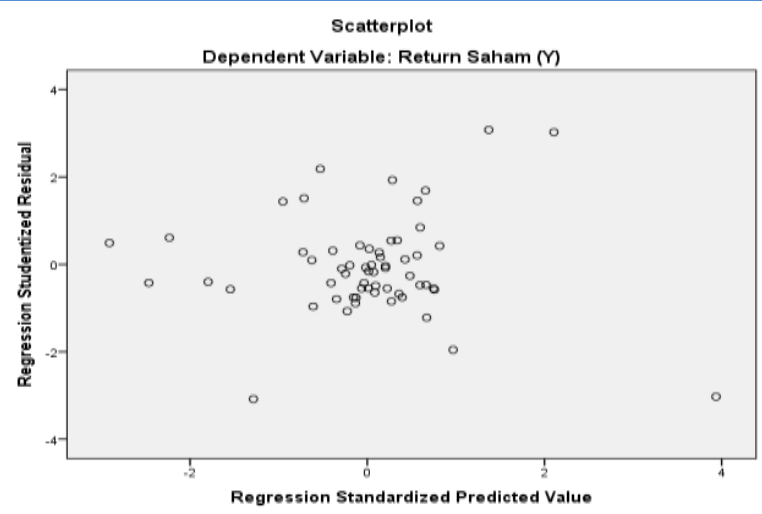

Sumber: Data Diolah

Gambar 3

Uji Heteroskedastisitas

Tabel 5

Uji F

ANOVA $^{\mathrm{a}}$

\begin{tabular}{|c|c|c|c|c|c|}
\hline$\overline{\text { Model }}$ & Sum of Squares & Df & Mean Square & $\mathrm{F}$ & Sig. \\
\hline Regression & 195169386,537 & 3 & 65056462,179 & 6,893 & $\overline{0,000 b}$ \\
\hline Residual & 528502844,254 & 56 & 9437550,790 & & \\
\hline Total & 723672230,791 & 59 & & & \\
\hline
\end{tabular}

a. Dependent Variable: Return Saham (Y)

b. Predictors: (Constant), Dividend Yield (X3), Laba Akuntasi (X1), Arus Kas Operasi (X2)

Sumber: Data Diolah

\section{Uji Signifikasi Simultan (Uji F)}

Berdasarkan Tabel 5, menunjukkan bahwa nilai Fhitung sebesar 6,893 dengan nilai signifikasi sebesar 0,00 lebih kecil dari a $(0,05)$, selanjutnya membandingkan Fhitung dengan Ftabel. Dimana jika Fhitung > Ftabel maka secara simultan variabel-variabel independen berpengaruh signifikan terhadap variabel dependen. Jadi nilai Fhitung > Ftabel $(6,893>3,20)$ atau nilai signifikansi $0,00<0,05$ sehingga Ho ditolak dan Ha diterima. Hal ini berarti Laba Akuntansi (X1), Arus Kas Operasi (X2) dan Dividend Yield (X3) secara bersama-sama (simultan) berpengaruh signifikan terhadap variabel dependen yaitu return saham pada perusahaan manufaktur di Bursa Efek Indonesia th 2015-2017.

\section{Uji t (Parsial)}

Berdasarkan tabel 6, pengujian hipotesis uji t diperoleh thitung masing- masing variabel yaitu Laba akuntansi $(X 1)=3,432$, arus kas operasi $(X 2)=2,384$, dividend yield $(\mathrm{X} 3)=0,582$. Nilai ttabel $=2.119$. Laba akuntansi thitung $>$ ttabel, dan tingkat signifikasi sebesar 0,001 $<0,05(5 \%)$ maka Hi diterima. Arus kas operasi thitung > ttabel, dan tingkat signifikasi sebesar $0,021<0,05(5 \%)$ maka Hi diterima. Dividend yield memiliki nilai thitung sebesar $-5,82$ sedangkan nilai ttabel adalah 2,119. Karena thitung < ttabel, dan tingkat signifikasi sebesar 0,56 > $0,05(5 \%)$. Hal ini menunjukkan bahwa hipotesa yang menyatakan Ho = Dividend Yield (X3) secara parsial (sendiri) berpengaruh negatif dan tidak signifikan terhadap return saham diterima. 


\begin{tabular}{|c|c|c|c|c|c|c|}
\hline & \multicolumn{6}{|c|}{$\begin{array}{c}\text { Tabel } 6 \\
\text { Uji t } \\
\text { Coefficients }^{\mathrm{a}} \\
\end{array}$} \\
\hline & \multirow[t]{2}{*}{ Model } & \multicolumn{2}{|c|}{$\begin{array}{l}\text { Unstandardized } \\
\text { Coefficients }\end{array}$} & \multirow{2}{*}{$\begin{array}{c}\begin{array}{c}\text { Standardized } \\
\text { Coefficients }\end{array} \\
\text { Beta }\end{array}$} & \multirow[t]{2}{*}{$\mathrm{t}$} & \multirow[t]{2}{*}{ Sig. } \\
\hline & & B & Std. Error & & & \\
\hline \multirow[t]{4}{*}{$\overline{1}$} & (Constant) & 840,161 & 443,654 & & 1,894 & ,063 \\
\hline & Laba Akuntasi (X1) & $2,419,549$ & 705,029 & ,396 & 3,432 &, 001 \\
\hline & Arus Kas Operasi (X2) & 297,393 & 124,732 & 275 & 2,384 &, 021 \\
\hline & Dividend Yield (X3) & $-8,408$ & 14,447 &,- 066 &,- 582 &, 563 \\
\hline
\end{tabular}

Sumber: Data Diolah

\section{Uji Dominan}

Dalam meningkatkan return saham pada perusahaan manufaktur maka dilakukan dengan melihat ranking koefisien regresi yang di standartkan $(\beta)$ atau standardized of coefficient beta. Nilai standardized of coefficient beta laba akuntansi sebesar 0,396, arus kas operasi sebesar 0,275 dan dividend yield sebesar -0,066. Dapat disimpulakan bahwa variable yang mempunyai nilai standardized of coefficient beta paling tinggi adalah variabel laba akuntansi. Dengan demikian variabel laba akuntansi merupakan variabel yang dominan pengaruhnya terhadap return saham.

\section{SIMPULAN}

Variabel Laba Akuntansi (X1), Arus Kas Operasi (X2) dan Dividend Yield (X3) secara bersama-sama (simultan) berpengaruh signifikan terhadap return saham pada perusahaan manufaktur yang terdaftar di Bursa Efek Indonesia diterima. Laba akuntansi (X1) terbukti secara parsial (sendiri) berpengaruh positif dan signifikan terhadap return saham. Variabel arus kas operasi (X2) terbukti secara parsial (sendiri) berpengaruh positif dan signifikan terhadap return saham. Variabel dividend yield (X3) terbukti secara parsial (sendiri) berpengaruh negatif dan tidak signifikan terhadap return saham. Laba akuntansi (X1) memiliki pengaruh yang lebih dominan terhadap return saham dibandingkan dengan arus kas operasi dan dividend yield.

\section{DAFTAR PUSTAKA}

Tandelilin, E. 2001, Analisis Investasi dan Managemen Fortofolio. BPFE, Yogjakarta. Ghozali, Chariri 2016, Teori Akuntansi, Universitas Diponegoro, Semarang.

Husnan 1998, Dasar-dasar Portofolio dan Analisis Sekuritas, UPP AMP YKPN, Yogyakarta.

Hirt, Block. 2006, Fundamentals of Investment Management, 8th Edisi, Mc Graw Hill International Edition. 